\title{
IS AFVOER DER OMBILIËNN-KOLEN OOSTWAARTS IN DEN EERSTEN TIJD DENKBAAR?
}

\section{Aan de Redactie van De Economist.}

In uw "Naschrift" tot het artikel van den heer Cluysenaer in het Mei-nummer van De Economist, geschreven naar aanleiding van het flinke adres der Padangsche kamer van koophandel voor spoorwegaanleg en kolenontginning in het gouvernement van Sumatra's Wostkust, zegt gij wel zeer terecht ten slotte, blz. 498, dat het wat laat zou zijn om de decisie op aanvragen voor spoorwegaanleg van het Ombiliën-steenkolenveld naar de Westkust thans nog van het onvoldoende onderzoek der oostelijke richting afhankelijk te maken. Evenzeer terecht zegt gij, dat er veel voor schijnt te zeggen thans niet over de voorkeur te twisten, doch het meest voor de hand liggende, d. i. den afvoer westwaarts, waarvoor meerdere concessie-aanvragen zijn ingediend, te volbrengen. Toch blijkt uit uw "Naschrift" in zijn geheel dat gij aan dien afvoer oostwaarts groote waarde hecht en ze niet ondoenlijk acht.

Vergun mij, wat dit laatste betreft, met $\mathbf{u}$ in gevoelen te verschillen.

In uw "Naschrift" herinnert gij aan ${ }_{n}$ de vrij aannemelijke bedenkingen" der hh. Claysenaer en Veth „de laatste vroeger sterk voorstander der oostelijke richting", in de vergadering van het Indisch Genootschap van 12 Februari jl. tegen den oostelijken afvoer aangevoerd. Gij voegt er echter bij: „niettemin blijft het een feit dat die richting niet genoegzaam is onderzocht" euz. Bij herlezing van hetgeen de heer Veth zei, zie Handelingen Ind. Gen., 1884, p. 77, vooral bij kennisname van hetgeen over dit onderwerp voorkomt in het groote werk der Sumatra-expeditie, zoudt gij, ik houd er mij van overtuigi, tot de meening komen, ik zeg niet met den beer Veth dat "nooit aan een afvoer oostwaarts zal kunnen gedacht worden," want ik wil de mogelijkheid 
niet uitsluiten dat die eenmaal uitvoerbaar zal blijken, maar dat aan dien afvoer oostwaarts in den eersten tijd onmogelijk te denken is.

Er is niet aan te denken, niet slechts om de terrein-moeilijkheden, waarvan in het Indisch Genootschap sprake was, maar ook om een politieke reden, welke in het Genootschap onbesproken bleef, maar waarop wel degelijk werd gewezen bij de herhaalde bespreking van dit onderwerp in de Koloniale Kroniek. Vergun mij daarom $u$, en uwe lezers, te herinneren aan het daaromtrent voorkomende ond. and. in de Kol. Kron. in de Economist van October 1879 , p. 768 en 775 en in Econ. Maart 1882 , p. 262. Daar is er op gewezen dat, daargelaten nog de inderdaad zeer groote, wellicht onoverkomelijke terrein-moeilijkheden, bezwaren van staatkundigen aard, het verzet van den radja van Sigoentoer tegen het betreden van zijn gebied door vreemdelingen, het leggen van een spoorweg oostwaarts onmogelijk maken, zoolang ons gouvernement in die streken niet volkomen meester is.

Met mij zult gij het wel even weinig waarschijnlijk als gewenscht achten, dat het gouvernement trachte dat vorstje door geweld tot andere meening te brengen. Van den tijd, dien grooten heelmeester, zal ook in dit opzicht verbetering moeten worden verwacht. Maar nu zoowel terrein-moeilijkheden als bezwaren van politieken aard aan den afvoer der Ombiliënvelden oostwaarts in den weg staan, is er te meer reden dat er ten aanzien der sedert zoovele jaren aanhangige concessie-aanvragen door afvoer Westwaarts, waarvoor de Kamer van Koophandel te Padang, gelijk de heer Cluysenaer zoo terecht aantoonde, weder een zoo flink pleidooi hield, eindelijk door de Regeering eene beslissing worde genomen. Men bedenke toch dat het hier niet alleen geldt de ontginning van een uiterst rijk kolenveld, maar ook de welvaart van een der rijkste, best bevolkte, meest belangrijke onzer bezittingen, voor welker verdere ontwikkeling, volgens het getuigenis van tal van bevoegde beoordeelaren, spoorwegaanleg dringend noodig is.

Spoorwegaanleg in het gouvernement van Sumatra's Westkust zonder kolenontginning in den eersten tijd niet rentabel. Ontginning van het Ombiliën.kolenveld zonder spoorwegaanleg schier ondenkbaar. Beiden vereenigd rentabel en hoogst gewenscht om Midden-Sumatra tot grooter ontwikkeling te brengen en Indië in eigen boezem te voorzien van steenkolen van uitmuntende qualiteit. Ziedaar de stellingen door de concessie-aanvragers sedert eene nu reeds lange reeks van jaren telkens en telkens betoogd, en nu 
weder door de Padangsche Kamer van koophandel met kracht aangedrongen, met aantooning tevens van de belangrijke directe voordeelen, welke voor het gouvernement uit dien spoorwegen die kolen-exploitatie zullen voortspruiten.

$\mathrm{Zal}$ het gouvernement niet eindelijk eene beslissing ter zake nemen? Zoo niet, zal de Tweede Kamer zich dan blijven beperken tot de schier jaarlijks herhaalde vraag: hoe het staat met de concessieaanvragen voor spoorwe ;aanleg en kole texploit,utie in MiddenSumatra? Zal zij niet"krachtig op het nemen eener beslissing aandringen?

10 Mei 1884. J. K. W. QUARLES VAN UFFORD. 